\title{
COMUNICATION
}

\section{NEW PROPOSAL OF CLASSIFICATION OF SEEDS BASED ON FORMS OF PHYTOCHROME INSTEAD OF PHOTOBLASTISM}

\author{
MASSANORI TAKAKI ${ }^{1}$ \\ Departamento de Botânica - UNESP/Rio Claro - SP
}

\begin{abstract}
The paper proposes the classification of seeds in relation to the forms of phytochrome instead of classical photoblastism. On the basis of published data all seeds have phytochrome and the term photoblastism should be replaced by forms of phytochrome that control germination: 1. Positive photoblastic seeds have phyB (and, to a lesser extent, phyD and phyE) controlling the germination process through Low Fluence Responses (LFR); 2. Negative photoblastic seeds have phyA controlling germination through High Irradiance Responses (HIR) and, when the pre-existing Pfr level is high enough to induce germination in darkness, through LFR by phyB; and 3. light insensitive seeds have phyA controlling germination through Very Low Fluence Responses (VLFR).
\end{abstract}

ADDITIONAL INDEX TERMS: Seed classification, photoblastism, phytochrome forms, mode of action.

\section{NOVA PROPOSTA DE CLASSIFICAÇÃO DAS SEMENTES BASEADA NAS FORMAS DO FITOCROMO AO INVÉS DO FOTOBLASTISMO}

RESUMO - Propomos no presente trabalho a classificação das sementes em relação às formas do fitocromo em vez de fotoblastimo. Com base nos dados publicados podemos afirmar que todas as sementes contém fitocromo e o termo fotoblastismo deve ser substituído pelas formas do fitocromo que controlam a germinação. 1. Sementes fotoblásticas positivas tem fiB (e, em menor extensão, fiD e fiE) controlando o processo de germinação através da resposta de fluência baixa (RFB); 2. Sementes fotoblásticas negativas tem fiA controlando a germinação através da resposta de irradiância alta (RIA) e, quando o nível de Fve pré-existente é alto o suficiente para induzir a germinação no escuro, através da RFB pelo fiB; e 3. Sementes insensíveis à luz tem fiA controlando a germinação através da resposta de fluência muito baixa (RFMB).

TERMOS ADICIONAIS PARA INDEXAÇÃO: Classificação de sementes, fotoblastismo, formas do fitocromo, modo de ação.

Received: 6/12/2000 - Accepted: 12/3/2001

1. Departamento de Botânica - UNESP - Caixa Postal 199 - Rio Claro - SP 13506-900 e-mail: massa@rc.unesp.br 
The classification of seeds in three categories according to their sensitivity to white light, called photoblastism (Vazquez-Yanes and Orozco-Segovia, 1993), can be associated with the recent advances in research on phytochrome forms and mechanisms of action. According to this classification the first category is termed positive photoblastic, in which seeds germinate only under white light; the second category is negative photoblastic, in which seeds germinate only in the dark and white light inhibits germination, and finally the third category is that of light insensitive seeds, in which seeds germinate both in the dark and under white light. The involvement of phytochrome in the control of photosensitive seeds has been recently discussed by Casal and Sánchez (1998).

The term phytochrome refers to a family of chromoproteins with molecular mass of about $125 \mathrm{KDa}$ (Kretsch et al., 2000). Two stable forms are present in plant tissues: $\mathrm{Pr}$, or the inactive form of phytochrome which absorbs light of $665 \mathrm{~nm}$, and Pfr, or the active form of phytochrome, responsible for promotion of several processes, which absorbs light of $735 \mathrm{~nm}$; the two forms are photoconversible (Mancinelli, 1996).

The physiological effects of phytochrome can be classsified based on three distinct mechanisms: 1. Low Fluence Responses (LFR), representing the classical red/far red reversible responses, in which production of Pfr promotes responses by plants and removal of Pfr reverses the response; 2. Very Low Fluence Responses (VLFR), representing the saturation of responses by very low fluences with reciprocity but without reversibility because the photoequilibrium mantained by far red light or even the dim green safe light used in photomorphogenic experiments produces enough Pfr to saturate these responses; 3. High Irradiance Responses (HIR), representing the responses produced by prolonged high irradiance, which do not show reciprocity or reversibility.

Five differents phytochromes in Arabidopsis thaliana (phyA, phyB, phyC, phyD and phyE) are encoded by five genes, $P H Y A$,
PHYB, PHYC, PHYD and PHYE (Smith, 1994). PhyA is responsible for VLFR, permitting seeds to perceive light of very low fluences. Scopel et al. (1991) observed in Datura ferox that induction of seed germination by burial was due to phytochrome through VLFR. PhyB is responsible for detection of changes in the red:far red ratio (R/FR) of canopy filtered light (Ballaré \& Casal, 2000) and controls seed germination by LFR (Shinomura et al., 1996). Other phytochromes, phyD and phyE, are also responsible for detection of R/FR (Schmitt et al., 1999). PhyB and phyD share nearly $80 \%$ of amino acid sequence identity and phyE 55\% (Devlin et al., 1998). PhyB, phyD and phyE are considered to be forms of a subgroup of PHY genes. PhyA is responsible for HIR and VLFR (Smith, 1994; Schmitt et al., 1999).

Kendrick and Frankland (1969), using negative photoblastic seeds of Amaranthus caudatus, concluded that phytochrome controls germination through HIR, because only continuous and/or intermittent white light inhibits germination. On the basis of current knowledge of phytochrome forms and actions we can conclude that phyA is the form of phytochrome responsible for germination control in negative photoblastic seeds.

Changes in the light effects on seed germination by external factors can be enumerated, as the following examples show:

McDonough (1967) demonstrated for non-photoblastic seeds of Raphanus sativus that white light inhibits germination when the seeds are osmotically treated. Thanos and Mitrakos (1979) suggested the involvement of phytochrome in the inhibition of germination of non-photoblastic caryopses of Zea mays by osmotic treatment. Freitas and Takaki (1992) studied the fluence response curves and proposed that phytochrome is responsible for the control of seed germination in $R$. sativus under water stress, possibly through HIR, confirming data of Guardia et al. (1987) in which intermittent white light had the same effect as continuous white light in the inhibition of germination under osmotic treatment. Lopes and Takaki (1987) observed for Phaseolus vulgaris, which has non-photoblastic seeds, that water stress 
promoted by polyethylene glycol resulted in the same induction of negative photoblastism. Takaki (1990) and Takaki and Toledo (1991) observed the same effect in seeds of Oryza sativa. These results indicate that phytochrome is present in nonphotoblastic seeds and that under specific conditions its presence can be demonstrated. Because continuous and/or intermittent light showed an effect on germination, phytochrome acts through HIR and we can conclude that phyA is the form of phytochrome present in those seeds. Casal and Sánchez (1998) suggested that short FR irradiation can decrease the germination percentage in dark germinating seeds when Pfr is present in large amounts, characterizing LFR mediated by phyB. However, in some species the amount of Pfr after short FR irradiation is sufficient to induce germination by VLFR mediated by phyA. Therefore, we have to separate these two distinct cases, both classified as dark germinating seeds. In the first case seeds germinate in darkness due to the high pre-existing Pfr level (LFR) and in the second case the low Pfr level is enough to induce germination (VLFR).

Smith (1976) demonstrated that seeds of Lactuca sativa L. cv. Grand Rapids can be classified as non-photoblastic at low temperatures and positive photoblastic in the range of $20-30{ }^{\circ} \mathrm{C}$. The explanation for the light insensitivity was that at low temperatures the rate of dark reversion is very low and Pfr is maintained above the threshold needed for induction of germination (Kendrick, 1976). Takaki et al. (1981) demonstrated with Rumex obtusifolius that as little as 5 minutes at 35 ${ }^{\circ} \mathrm{C}$ induced dark germination of positive photoblastic seeds, overcoming the light requirement. By analyses of fluence response curves, Takaki et al. (1985) suggested that factor(s) other than phytochrome could be involved in the process. The explanation of these results and those of Kendrick and Cone (1985) is that at least two forms of phytochrome are involved in the process: phyA after a short high-temperature treatment through VLFR, and phyB which controls germination without high-temperature treatment through LFR. Takaki and Zaia (1984) obtained the same effect of high temperature on seeds of Lactuca sativa.

Felippe and Polo (1983) reported for some weed species that scarification of positive photoblastic seeds changed the sensitivity to white light and these seeds germinated under both white light and darkness. Takaki and Gama (1998) showed for L. sativa that, when the integrity of the seed coat is lost, the control of germination changes from LFR to VLFR. Intact seeds germinate only under white light and scarified seeds germinate under both dark and light. On the basis of phytochrome forms, we can suggest that germination of lettuce seeds is controlled by phyB (LFR), but scarification induces phyA to promote germination (VLFR) since seeds germinate under both white light and darkness. As reported above, phyA seems to be responsible for the perception by seeds of the water potential of the media inducing osmolyte synthesis to counteract the pressure needed for rupturing the seed coat. Chacur and Takaki (1996) confirmed the interaction of seed coat integrity and phytochrome in negative photoblastic seeds of Cucumis anguria. The authors observed that naked seeds germinated both in the dark and under white light, however, incubation of these seeds at a low water potential resulted in restoration of light sensitivity.

Ladeira et al. (1987) observed that maturation of seeds of Plantago tomentosa under different light conditions resulted in different germination controls. Seeds matured under natural conditions germinated under continuous white light faster than in the dark. One possibility is that the dim green safe light used for scoring germinated seeds induced germination by VLFR of phytochrome action. Another possibility is that the level of pre-existing Pfr is near the threshold and slowly induced germination by LFR. When seeds were matured under complete darkness, low germination was observed in the dark and complete germination under white light, indicating a LFR. These results indicate that detailed work must be carried out on synthesis of different forms of phytochrome under different light conditions during development and maturation. 
On the basis of data here reported we propose that all seeds have phytochrome and the term photoblastism should be replaced by forms of phytochrome that control germination: 1. Positive photoblastic seeds have phyB (and, to a lesser extent, phyD and phyE) controlling the germination process through LFR; 2. Negative photoblastic seeds have phyA controlling germination through HIR and, when the preexisting Pfr level is high enough, germination is induced in the dark through LFR by phyB; and 3 . light insensitive seeds have phyA controlling germination through VLFR.

\section{ACKNOWLEDGEMENTS}

M.T. was supported by grants from CNPq, FAPESP and FUNDUNESP. M.T. is a CNPq Research Fellow.

\section{REFERENCES}

BALLARÉ, C.L. \& CASAL, J.J. Light signals perceived by crop and weed plants. Field Crops Research, 67: 149-160, 2000.

CASAL, J. J. \& SÁNCHEZ, R. A. Phytochromes and seed germination. Seed Science Research, 8: 317-329, 1998.

CHACUR, M.M. \& TAKAKI, M. Effect of tegument integrity on the light sensitivity in seeds of Cucumis anguria L. Brazilian Archives of Biology and Technology, 39: 1037-1042, 1996.

DEVLIN, P.F.; PAPEL, S.R. \& WHITELAM, G.C. Phytochrome E influences internode elongation and flowering time in Arabidopsis. The Plant Cell, 10: 1479-1487, 1998.

FELIPPE, G.M. \& POLO, M. Germinação de ervas invasoras: efeito de luz e escarificação. Revista Brasileira de Botânica, 6: 55-60, 1983.
FREITAS, N.P. \& TAKAKI, M. Phytochrome controlled seed germination in light insensitive seeds of Raphanus sativus L. cv. Redondo Gigante. Brazilian Archives of Biology and Technology, 35: 609-612, 1992.

GUARDIA, M.C.; CARAMELLO, K.A. \& TAKAKI, M. Osmotically induced light sensitivity in seeds of Raphanus sativus L. Brazilian Archives of Biology and Technology, 30: 665-670, 1987.

KENDRICK,R.E. Photocontrol of seed germination. Science Progress, 63: 347-367, 1976.

KENDRICK, R.E. \& CONE, J.W. Biphasic fluence-response for induction of seed germination. Plant Physiology, 79: 299-300, 1985.

KENDRICK, R.E. \& FRANKLAND, B. Photocontrol of germination in Amaranthus caudatus. Planta, 85: 326-329, 1969.

KRETSCH, T.; POPPE, C. \& SCHAFER, E. A new type of mutation in the plant photoreceptor phytochrome B causes loss of photoreversibility and an extremely enhanced light sensitivity. The Plant Journal, 22: 177$186,2000$.

LADEIRA, A.M.; GUARDIA, M.C. \& TAKAKI, M. Manipulation of seed germination in Plantago tomentosa Lam. and Raphanus sativus L. Seed Science and Technology, 15: 55-63, 1987.

LOPES, V.B. \& TAKAKI, M. Seed germination in Phaseolus vulgaris L. I. Osmotic effect on light sensitivity. Brazilian Archives of Biology and Technology, 30: 641-647, 1987.

MCDONOUGH, W.T. Dormant and non-dormant similar germination responses when osmotically inhibited. Nature, 214: 11471148, 1967. 
SHINOMURA, T.; NAGATANI, A HANZAWA, H.; KUBOTA. M.; WATANABE, M. \& FURUYA, M. Action spectra for phytochrome A- and phytochrome B-specific photoinduction of seed germination in Arabidopsis thaliana. Proceedings of the National Academy of Sciences, USA, 93: 8129-8133, 1996.

SCHMITT, J.; DUDLEY, S.A. \& POGLIUCCI, M. Manipulative approaches to testing adaptive plasticity: phytochrome-mediated shadeavoidance responses in plants. The American Naturalist, 154: S43-S54, 1999.

SMITH, H. Sensing the light environment: the functions of phytochrome family. In: Photomorphogenesis in plants. 2nd ed. Kendrick, R.E. \& Kronenberg, G.H.M. Kluwer Academic Publishers, Dordrecht, 377-416, 1994.

TAKAKI, M. Effect of water stress on seed germination and seedling growth in Oryza sativa L. Biologia Plantarum, 32: 238-240, 1990.

TAKAKI, M. \& GAMA, L.H.P. The role of the seed coat in phytochrome-controlled seed germination in Lactuca sativa L. cv. Grand Rapids. Seed Science and Technology, 26: 355-362, 1998.
TAKAKI, M.; HEERINGA, G.H.; CONE, J.W. \& KENDRICK, R.E. Analysis of the effect of light and temperature on the fluence response curves for germination of Rumex obtusifolius. Plant Physiology, 77: 731-734, 1985.

TAKAKI, M.; KENDRICK, R.E. \& DIETRICH, S.M.C. Interaction of light and temperature on the germination of Rumex obtusifolius. Planta, 152: 209-214, 1981.

TAKAKI, M. \& TOLEDO, J.C. Effect of imbibition and scarification on the sensitivity to water stress in seeds of Oryza sativa L. Seed Science and Technology, 19: 263-268, 1991.

TAKAKI, M. \& ZAIA, V.M. Light and temperature on lettuce seed germination. Planta, 160: 190-192, 1984.

THANOS, C.A. \& MITRAKOS, K. Phytochromemediated germination control of maize caryopses. Planta, 146: 415-417, 1979.

VAZQUEZ-YANES, C. \& OROSCOSEGOVIA, A. Patterns of seed longevity and germination in the tropical rainforest. Annual Review of Ecology and Systematics, 24: 69-87, 1993. 